Sitasi artikel ini (APA $6^{\text {th }}$ Edition style):

Arsa, D. (2018). Sudut Pandang Indonesia atas Periode Kamp, 1942-1945. MUKADIMAH, 1(2), 152-159.

\title{
Sudut Pandang Indonesia atas Periode Kamp, 1942-1945
}

\author{
Dedi Arsa \\ Program Studi Sejarah Peradaban Islam, Fak. Ushuluddin, Adab, dan Dakwah, \\ IAIN Bukittinggi \\ deddyarsya1987@gmail.com
}

\begin{abstract}
ABSTRAK
Periode Jepang di Indonesia (1942-1945) bagi kebanyakan orang Eropa dan Indo-Eropa di Indonesia dikenang sebagai Periode Kamp, sebuah periode yang disebut-sebut sebagai periode yang "membingungkan sekaligus mengerikan". Selama periode ini hampir seluruh orang Eropa dan Indo-Eropa yang ada di Indonesia dimasukkan ke dalam kamp-kamp tawanan/kerja paksa yang tersebar di berbagai tempat di Indonesia. Periode ini tampak begitu membekas dalam ingatan mereka, terutama bagi yang pernah merasakan langsung diinternir. Tulisan ini menelaah bagaimana pandangan (sudut pandang) orang Indonesia tentang interniran Eropa dalam kamp Jepang, dengan menelaah dua karya dengan topik tersebut yang ditulis orang Indonesia: sebuah otobiografi dengan tajuk Sebastian Tanamas, Tak Menggantang Asap: Otobiografi Seorang Pejuang dan Pengusaha Industri Kerajinan, dan sebuah roman berjudul Dan Perang pun Usai. Penyusunan tulisan ini menggunakan metode penyusunan yang dikenal pada umumnya dalam metode penyusunan sejarah modern, yaitu meliputi empat tahapan: heuristik berupa pengumpulan bahan/sumber, kritik sumber berupa kritik intern-ekstern, interpretasi, dan penulisan dalam bentuk historiografi.
\end{abstract}

Kata kunci: Sudut pandang, Periode Kamp, Jepang.

\section{PENDAHULUAN}

Banyak di antara mereka meninggalkan kenang-kenangan tentang masa-masa dalam kamp; mereka menyebut periode itu sebagai "tahun-tahun keras tanpa masa depan", kadang ditulis "laksana neraka". Kenang-kenangan itu dituangkan dalam bentuk novel-roman maupun memoir yang nyaris semuanya ditulis dari sudut pandang Eropa sebagai si korban. Namun, bagaimana pandangan orang Indonesia mengenai periode tersebut tidak banyak diketahui.

Tetapi, untuk melakukan itu terlebih dahulu perlu juga diajukan pertanyaan apa-apa saja karya-karya jenis kamp yang pernah ada dan kecenderungan dari setiap karya-karya tersebut. Karena objeknya adalah interniran Eropa, maka tulisan ini memang mengarahkan perhatiannya pada orang-orang asing (Belanda-Eropa) di kawasan Indonesia pada satu periode penting sejarah Indonesia. Boleh saja disebut tulisan ini agak bercorak 
Nederland-sentris, tak apalah, namun toh sejarah orang-orang asing di Indonesia tidak perlu dikesampingkan begitu saja, mereka juga pernah bagian dari sejarah bangsa ini. Bagi para sejarawan, sebagaimana dikatakan Onghokham, setiap periode sejarah adalah penting, menarik hati, dan juga berharga (Onghokham, 1987, p. vii).

Tulisan ini adalah karya sejarah dengan spesifikasi tematik sejarah karya sejarah (historiografi), menelaah perkembangan karya-karya sejarah (dalam hal ini termasuk sastra) dalam tema tertentu (dalam hal ini tentang karya-karya jenis kamp-dan lebih fokus lagi yang ditulis oleh orang Indonesia). Karena yang dianalisis di antaranya adalah karya sastra, pendekatan yang dipakai dalam tulisan ini juga adalah pendekatan yang dikenal umumya dalam penelitian sastra dengan konten-konten sosial-historis, yaitu pendekatan newhistorisism. Dalam pandangan ini, fakta dan fiksi tidak terpisahkan, sastra dan sejarah telah lesap batas; pandangan ini tidak memisahkan karya sastra dengan zamannya. Seperti yang dikatakan salah seorang penganjurnya, Louis A. Montrose, "membaca sastra sama dengan membaca sejarah, membaca sejarah sama dengan membaca sastra" (Melani Budianta, 2006).

\section{METODE DAN FOKUS PENELITIAN}

Penyusunan tulisan ini menggunakan metode penyusunan yang dikenal pada umumnya dalam metode penyusunan sejarah modern (Kuntowijoyo, 2003), yaitu meliputi empat tahapan: heuristik berupa pengumpulan bahan/sumber (Gottschalk, 1985), kritik sumber berupa kritik intern-ekstern, interpretasi (Garaghan, 1984), dan penulisan dalam bentuk historiografi. Heuristik merupakan tahap pencarian dan pengumpulan sumber-sumber sejarah (Kuntowijoyo, 2003). Sementara kritik sumber dapat dibagi atas kritik ektern dan intern. Kritik ekstern dilakukan untuk mencari otentisitas arsip dan dokumen yang sudah didapatkan. Sedangkan kritik intern dilakukan terhadap isi dokumen yang otentik tersebut untuk mendapat kevalidan data yang dikandungnya (Lloyd, 1993).

Lalu terhadap itu semua dilakukan analisis dan sintesis data, di mana fakta yang diperoleh lalu dianalisis dengan menggunakan analisis prosesual dan struktural. Analisis prosesual digunakan guna menyusun karya-karya jenis kamp yang dapat terlacak, sementara analisis struktural (Kartodirdjo, 1993) digunakan untuk menganalisis bagaimana pandangan karya-karya jenis kamp yang tulis orang Indonesia dalam menggambarkan tawanan/interniran. Tahap keempat yaitu tahap penulisan laporan. Penulisan berbentuk sejarah-sastra mengenai pandangan orang Indonesia terhadap kaum interniran.

\section{HASIL DAN PEMBAHASAN}

\section{Karya-karya 'Jenis Kamp'}

Karya-karya 'jenis kamp', begitu Rob Nieuwenhuys menyebut, adalah karyakarya yang mengetengahkan kehidupan orang Eropa dalam kamp internir Jepang di Indonesia selama kurun 1942-1945. Kebanyakan ditulis oleh orang 
Eropa dan Indo-Eropa yang pernah merasakan langsung diinternir dalam bentuk novel dan memoir, atau menggabungkan keduanya. Bagaimana pandangan karya-karya tersebut terhadap penginterniran dan kaum internir?

Pans Schomper menulis sebuah buku berjudul Chaos After Paradise: Selamat Tinggal Hindia (Pans Schomper, 1996). Buku yang diterbitkan pada tahun 1996 ini menggambarkan bagaimana penderitaan orang Eropa dan IndoEropa dalam kamp Jepang. Tidak hanya melalui tulisan, tetapi gambaran penderitaan itu juga diperkuat melalui ilustrasi-karikatural. Sebuah karikatur dalam buku ini, misalnya, memperlihatkan seorang serdadu Jepang sedang berkacak pinggang dengan menopangkan sebelah tangannya pada sebuah pedang katana. Di belakangnya terlihat latar seorang tawanan yang tertelungkup. Di bawah karikatur itu tertulis "Jan de Mepper" - Tukang Tempeleng.

Judul buku ini sendiri-Chaos After Paradise-dengan tepat merepresentasikan gambaran nasib orang Eropa dan Indo-Eropa di Indonesia di mana mereka digambarkan telah menjadi korban keganasan dan kebiadaban rezim militer Jepang. Sebelum Jepang datang, berabad lamanya orang Eropa hidup di tanah jajahannya ini serupa hidup di surga. Namun, kedatangan Jepang membalikkan keadaan ini menjadi "laksana neraka".

Karya 'jenis kamp' lainnya adalah sebuah novel-memoir yang ditulis bekas interniran, Rita la Fontaine de Clercq Zubli, Disguised: Sang Penyamar: Memoar Masa Perang (Zubli, 2009). Novel ini menggambarkan kebingungan orang Eropa \& Indo-Eropa ketika Jepang berkuasa di atas bekas tanah jajahan mereka. Penderitaan orang-orang Eropa dan Indo-Eropa dalam kamp-kamp internir digambarkan dengan detail dalam novel ini. Rita, yang menghabiskan masa kecil bahagianya di Jambi kota bersama keluarganya yang terpandang, lalu harus menjalani petualangan menyedihkan dan menakutkan ketika Jepang datang, mengobrak-abrik rumah mereka, dan menggring keluarga itu ke dalam kamp sebagai tawana. Rita harus terpisah dari keluarganya, harus berpindah dari kamp ke kamp, harus menyamar menjadi laki-laki agar tidak diperkosa. Gambaran yang tampak menyedihkan belaka.

Begitupun beberapa memoir lain, di antaranya yang ditulis J. C. Bijkerk, Selamat Berpisah, Sampai Berjumpa di Saat yang Lebih Baik: Dokumenter Runtuhnya Hindia Belanda (Bijkerk, 1988), memberikan gambaran yang nyaris tidak jauh berbeda, tentang kehidupan orang-orang Eropa dan Indo-Eropa dalam kamp Jepang yang menderita. Dalam kamp Jepang, catatan-catatan bangsa Eropa maupun Indo-Eropa itu memberikan gambaran mengenai kesan putus asa, ketersiksaan, kekerasan, dan kekejaman. Kekerasan dan kekejaman yang tidak hanya dialami laki-laki, tetapi juga oleh para tawanan perang perempuan. Pemerkosaan terhadap beberapa tawanan perempuan adalah hal yang sering disebut-sebut kedua roman-memoir di atas.

Ada lagi roman-memoir yang ditulis seorang Indo-Belanda bernama Paula Gomes berjudul Sudah, Biar Saja (Gomes, 1975). Karya ini dianggap karya 
yang berhasil menghadirkan melankolia-dramatik tentang seorang produk jajahan berhadapan dengan negara masa silamnya yang traumatik ketika berada dalam kamp. Indonesia yang dikenalnya dulu ketika kekuasaan kolonial Belanda masih jaya, hadir dalam wajah yang berbeda di bawah kuasa Jepang; anak jajahan yang dulu patuh dan tunduk kini memandang tuan penjajahnya dengan pandangan menghina lagi tajam.

Bagi para internir, dalam gambaran karya tersebut di atas, kondisi yang dialami para tawanan Eropa seperti tamparan pada pipi kiri-kanan: Jepang menampar mereka dengan memasukkan mereka ke dalam kamp-kamp kerja paksa, sementara bekas anak jajahan tidak membela sama sekali atas nasib malang itu tetapi malah memberi satu lagi tamparan pada sisi pipi yang lain seolah-olah mereka bersyukur tuan penjajahnya dihumbankan ke dalam kampkamp kerja paksa oleh kekuatan baru yang menggantikan (Jepang). Ini menimbulkan kepedihan yang lain lagi, yang mungkin menambah menyakitkan lahir dan batin, bagi orang-orang Eropa \& Indo-Eropa dalam kamp Jepang, di samping penderitaan dalam kamp itu sendiri.

Di luar novel dan memoir, beberapa karya historiografi tentang Periode Kamp ini ditulis di antaranya oleh Hovinga, The Sumatra railroad: Final destination Pakan Baroe, 1943-1945 yang diterbitkan KITLV Leiden pada tahun 2010 (Hovinga, 2010). Susan Rodgers menulis artikel berjudul "A Nederlander Woman's Recollections of Colonial and Wartime Sumatra: From Sawahlunto to Bangkinang Internment Camp", yang diterbitkan jurnal Indonesia edisi 79 pada April 2005 (Susan Rodgers, 2005).

Artikel Hovinga membahas tentang proyek ambisius pembangun jalur kereta api yang direncanakan Jepang sejak dari Muara Sijunjung hingga ke Pekanbaru; proyek ini telah mengorbankan banyak tawasan Eropa sebagai pekerja-paksa. Sementara artikel Susan di antaranya membahas memoar seorang anak Belanda yang hidup dalam kebahagiaan keluarga Eropanya di Kota Sawahlunto, kota tambang emas hitam, yang kaya dan gemerlap pada periode ketika kekuasaan kolonial Belanda masih tegak, hingga ketika Jepang datang menguasai kota itu mereka harus tersuruk-suruk dalam kamp kerja paksa. Buku yang pertama mengekplorasi penderitaan para tawanan di mana buku itu diperlengkapi foto-foto tawanan yang kurus-kering lagi merasai. Sementara artikel yang terakhir ini seperti hendak menegaskan, betapa kehadiran Jepang hanya menimbulkan kesengsaraan, di mana mereka telah memutus jalan kemajuan yang dibikin Belanda selama berabad-abad sebelumnya di tanah Hindia.

\section{Perspektif Indonesia}

Di antara beberapa karya'jenis kamp' (yang terlacak) yang telah diuraikan di atas tampak bahwa karya tersebut hampir seluruhnya ditulis dari sudut pandang Eropa/Indo-Eropa. Tetapi bagaimana pandangan orang Indonesia? 
Di antara yang dapat ditelaah di sini adalah otobiografi seorang Indonesia bernama Sebastian Tanamas, seorang pejuang dan pengusaha industri kerajinan. Otobiografi dengan tajuk Sebastian Tanamas, Tak Menggantang Asap: Otobiografi Seorang Pejuang dan Pengusaha Industri Kerajinan (Yusra \& A.L., 1998). Karya ini diserahkah penulisannya kepada Abrar Yusra, penulis biografi ternama. Karya ini memang hanya membicarakan sedikit bagian saja dari periode mengerikan bagi orang Eropa dan Indo-Eropa itu: gambaran mula-mula para calon interniran (Eropa dan Indo-Eropa) sebelum dikirim ke kamp-kamp. Tetapi biografi ini menjadi penting karena mencatat bagaimana pribumi memandang Eropa \& Indo-Eropa yang akan dimasukkan ke dalam kamp konsentrasi oleh Jepang.

Otobiografi ini selengkapnya menceritakan tentang ditangkapnya serdadu-serdadu KNIL dan para pegawai bangsa Belanda yang ada di Padang pada awal Maret 1943 oleh Jepang. Di kota terbesar di Sumatra's Westkust itu, para Europeanen (orang-orang Eropa) dan Indo-Eropa digiring oleh serdadu Jepang ke Plain van Rome-lapangan luas di pusat kota itu (sekarang Taman Imam Bonjol) adalah tempat awal di mana para tawanan perang dibariskan dan didata untuk kemudian dikirim ke kamp-kamp kerja paksa yang mulai dibangun di beberapa titik di Sumatera Tengah. Beberapa pribumi Padang diperbantukan oleh militer Jepang untuk mengawal mereka.

Dalam ketika itu, di sinilah terlihat, bagaimana pribumi memandang para interniran dengan pandangan tak percaya: "tuan si Duli yang seakan tidak tergoyahkan dari kursinya dulu, kini harus terbungkuk-bungkuk bagai kucing kena lidi di hadapan orang-orang pendek dari tempat matahari terbit". Pandangan ini jelas pandangan merendahkan, sekalipun rasa keterheranan dan kasihan bisa jadi juga timbul melihat para tawanan, tetapi kita tidak bisa meneruskan paragraf ini karena memang sedikit itu saja keterangan yang didapatkan dari buku itu.

Selain otobiografi di atas, ada sebuah novel yang terbit pada tahun 1977 bertajuk Dan Perang pun Usai (Marahimin, 1977), yang memenangkan hadiah kedua Sayembara Mengarang Roman yang diadakan Dewan Kesenian Jakarta tahun yang sama. Karya ini adalah karya 'jenis kamp' yang ditulis oleh seorang Indonesia, dengan begitu karya ini adalah juga merepresentasikan perspektif orang Indonesia (pascakolonial) dalam memandang 'periode kamp'.

Cerita awal novel karangan Ismail Marahimin ini sesungguhnya adalah Tiga Lagu Dolanan, sebelum memakai judulnya yang sekarang. Dari judul awalnya itu, terlihat bahwa novel ini bercerita tentang nasib manusia dari tiga bangsa: Indonesia, Jepang, dan Belanda. Mari kita fokuskan pandangan mata pada yang terakhir saja, agar tidak membuat artikel ini melebar ke mana-mana. Nah, bagaimana novel ini menggambarkan orang-orang Belanda yang menjadi tawanan Jepang dalam kamp Jepang?

Latar cerita novel ini adalah Kamp Taratak Buluh, salah satu di antara banyak kamp interniran lainnya yang terserak dari Muara Sijunjung hingga ke 
Pekanbaru. Berjarak $17 \mathrm{~km}$ dari selatan Pekanbaru, ke kamp itulah ribuan banyaknya tawanan Eropa dan Indo-Eropa dikirim Jepang untuk bekerja paksa membangan jalur kereta api. Itu hanya salah satu kamp kerja paksa saja, sebab banyak kamp lain yang juga tidak kalah padat. Pengiriman ke berbagai kamp sepanjang Muara Siunjung dan Pekanbaru itu tercatat dimulai pada 17 dan 18 Oktober 1943, diangkut dari berbagai daerah dengan berbagai jenis transportasi. Menurut Children of War (Beudell, 1976, p. 21), anak-anak dan para wanita dikirim secara bergelombang satu dan dua bulan setelah dibuka, yaitu pada November hingga Desember 1943, mereka dikirim ke kamp khusus wanita dan anak-anak di Bangkinang, tidak jauh dari Taratakbuluh. Pada awal tahun 1944, 3 buah truk dari Jambi kota tiba membawa tawanan perang (Zubli, 2009, p. 30). Pada April 1944, para tawanan perang itu (sekali lagi) di-drop ke Bangkinang (Periksa arsip Overig Personeel: Uitgezonderd van het Korps Mariniers en de MLD, p. 88). Namun, pada bulan berikutnya, 14 Mei 1944, 1.937 tahanan perang dari Batalion 10 KNIL yang bermarkas di Batavia dikirim ke Padang dengan kapal uap. Mereka dirumahkan di gedung penjara di Padang, untuk besoknya dikirim ke Pekanbaru mengerjakan rel kereta api (Hovinga, 2010). Pada 16 September 1944, tiga bulan setelah kedatangan kapal pertama, sebuah kapal uap mendarat lagi di Teluk Bayur membawa interniran dari Pulau Jawa. Kapal perang angkatan laut Jepang itu membawa 4200 romusha dan 2300 tahanan perang lagi-lagi dari Batalion $10 \mathrm{KNIL}$. Mereka semuanya dimasukkan ke gedung penjara di Padang sampai tanggal 22 September 1944. Pada 22 September mereka dibawa ke Taratakbuluh yang menjadi latar novel ini.

Bagaimana novel ini memandang orang-orang Belanda dalam kamp Jepang itu? Berbeda dengan gambaran beberapa novel dan memoir yang telah diuraikan pada pasal sebelumnya, novel ini tampak tidak terlalu banyak mengekploitasi penderitaan para tawanan. Para interniran, kata novel ini, "melakukan tugasnya dengan baik".

“Orang-orang Belanda yang interniran itu bekerja terlalu bersunggung-sungguh. Tekun dan membisu, seperti serombongan semut, hampir tanpa kesalahan, hampir tidak perlu perintah dan petunjuk dari prajurit Jepang yang mengawal," tulis novel ini selengkapnya.

Kesan pesimistis, putus asa dan menyerah pada nasib, dalam karyakarya Eropa \& Indo-Eropa sebelum ini, kini digantikan dengan kesan yang lebih optimistik untuk berani melawan takdir. Dengan diam dan bersungguhsungguh bekerja, orang-orang Belanda itu sesungguhnya menyimpan sesuatu harapan dalam hati, kata novel ini pula. Wajah mereka kelihatan tegang, mendendam dan melakukan perhitungan. Sebab para tawanan, dalam novel ini, sedang menyiapkan sebuah pelarian diri. Yang juga menarik untuk dilihat adalah, pelarian diri itu dibantu orang-orang Indonesia - si bekas anak jajahan. Kliwon, pemuda bangsa Indonesia, membantu pelarian itu. Dibantu pribumi lain bernama Haji Zen, yang memberikan persediaan makanan dan alat-alat yang dibutuhkan untuk pelarian. Paktua Hasan bertindak sebagai penunjuk jalan ke desa terasing tempat bersembunyi tawanan kelak. Juga Lena, seorang 
perempuan pribumi lain yang merupakan kekasih Kliwon, ikut membantu pelarian.

Dalam pandangan novel ini, beberapa orang Indonesia yang membantu pelarian itu juga melakukannya tidak dari kesadaran mereka sendiri. Mereka mau membantu pelarian karena 'terpaksa' bersebab alasan-alasan tertentu. Kliwon, misalnya, tidak mempunyai hasrat untuk membantu para tawanan melarikan diri, namun karena aibnya banyak diketahui oleh Wimpie (salah seorang tawanan), seperti perbuatan maksiatnya bersama Lena serta perbuatan aib lainnya maka terpaksa dia harus menyetujui membantu pelarian.

Begitupun dengan Lena, dia ikut membantu pelarian sebab dia tidak rela Kliwon meninggalkannya padahal Kliwon sudah sering menidurinya. Namun, sekalipun begitu, tak dapat dielakkan bahwa novel ini melihat orang Indonesia masih memandang bekas tuan penjajahnya (Belanda) dengan pandangan yang bersahabat. Di luar Kliwon dan Lena, ada Haji Zen dan Paktua Hasan yang membantu pelarian diri para tawanan itu tanpa tendensi apa pun selain alasan humanistis belaka.

Gambaran tersebut, sekali lagi, juga berbeda dengan beberapa memoir atau novel-memoir yang ditulis pengarang Eropa dan Indo-Eropa yang disebutkan sebelumnya. Orang Indonesia tidak seperti anggapan penulispenulis Belanda dan Indo-Belanda yang memandang bahwa bekas anak jajahan mereka telah memandang bekas tuan jajahannya dengan pandangan 'membenci'. Alih-alih, novel ini menyatakan bahwa orang Indonesia ternyata betul-betul telah menjadi pemaaf, entah dalam pengertian buruk atau baik, yang dengan segera lagi cepat bersahabat dengan para interniran (yang notebenenya adalah bekas penjajah mereka sebelumnya) dan bahkan lebih jauh lagi mau mengorbankan nyawanya untuk menyelematkan mereka.

\section{PENUTUP}

Drama penderitaan itu berakhir ketika kekuasaan Jepang berakhir pada 1945. Serdadu Belanda yang datang dari negeri induk dengan diboncengi pasukan sekutu mencoba merebut lagi tanah jajahan yang pernah lepas. Jepang diusir, dan kamp-kamp konsenstrasi kaum internir direbut, dan kamp-kamp kerja paksa dibubarkan penguasa baru. Seluruh tawanan perang bangsa Eropa tanpa terkecuali dibebaskan. Banyak di antara mereka yang kemudian dipulangkan dengan kapal uap ke negeri induk, menjalani hidup sebagaimana kebanyakan orang Belanda lainnya, dan menganggap derita dalam kamp-kamp interniran hanya sebuah episode masa silam yang telah lewat, beberapa yang lain menuliskan kepahitan hidup dalam kamp dalam berbagai karangan.

Karya-karya 'jenis kamp' yang pernah ditulis orang Eropa dan IndoEropa berupa novel dan memoir, dan penggabungan keduanya. Pada umumnya karya-karya tersebut menggunakan sudut pandang 'Eropa sebagai si korban', di mana karya-karya ini cenderung mengekploitasi penderitaan para tawanan dalam kamp-kamp konsentrasi. Kesan pesimistis, putus asa dan menyerah pada 
nasib dalam karya-karya Eropa \& Indo-Eropa tergambar pada karya-karya itu. Kesan ini digantikan dengan kesan yang lebih optimistik pada karya yang ditulis orang Indonesia dalam memandang 'periode kamp' orang Eropa/Indo ini. Karya-karya tentang kamp memang sangat sedikit di antaranya ditulis oleh orang Indonesia (di antaranya yang terpenting adalah Dan Perang Pun Usai), namun di antara yang sedikit itu memiliki pandangan yang berbeda sama sekali dengan karya pengarang Eropa-Indo tentang topik yang sama.

\section{REFERENSI}

Beudell, A. M. (1976). Children of War (Vol. 4). New York: Vantage Press.

Bijkerk, J. C. (1988). Selamat Berpisah, Sampai Berjumpa di Saat yang Lebih Baik: Dokumenter Runtuhnya Hindia Belanda. Jakarta: Penerbit Djambatan.

Garaghan, G. J. (1984). A Guide to Historical Method. New York: Fordham University Press.

Gomes, P. (1975). Sudah, Biar Saja... (C. Arifin, Trans.). Jakarta: Djambatan.

Gottschalk, L. (1985). Mengerti Sejarah. (N. Notosusanto, Trans.). Jakarta: Universitas Indonesia Press.

Hovinga, H. (2010). The Sumatra railroad: Final destination Pakan Baroe 1943-1945. The Sumatra Railroad: Final Destination Pakan Baroe 1943-1945. Leiden: KITLV. https:/ / doi.org/10.1163/9789004253711

Kartodirdjo, S. (1993). Pendekatan Ilmu Sosial dalam Metodologi Sejarah. Jakarta: Gramedia.

Kuntowijoyo. (2003). Metodologi Sejarah. Yogyakarta: Tiara Wacana.

Lloyd, C. (1993). The Structure of History. Cambridge: Blackwell.

Marahimin, I. (1977). Dan Perang Pun Usai. Jakarta: Pustaka Jaya.

Melani Budianta. (2006). Budaya, Sejarah \& Pasar: New Historisisme dalam Perkembangan Kritik Sastra. Susastra: Jurnal Ilmu Sastra Dan Budaya, 2(3), 1-19.

Onghokham. (1987). Runtuhnya Hindia Belanda. Jakarta: Gramedia.

Pans Schomper. (1996). Chaos After Paradise: Selamat Tinggal Hindia. Janjinya Pedagang Telur. (T. Slamet, Trans.). Jakarta: PT Dorned.

Susan Rodgers. (2005). A Nederlander Woman's Recollections of Colonial and Wartime Sumatra: From Sawahlunto to Bangkinang Internment Camp. Indonesia, 79, 93-129.

Yusra, A., \& A.L., S. (1998). Sebastian Tanamas, Tak Menggantang Asap: Otobiografi Seorang Pejuang dan Pengusaha Industri Kerajinan. Jakarta: Gramedia.

Zubli, R. la F. de C. (2009). Disguised: Sang Penyamar (Memoar Masa Perang). Jakarta: Gramedia. 
